\title{
Introducing Takaful in India: An Exploratory Study on Acceptability, Possibility and Takaful Model
}

\author{
Sheila Nu Nu Htay ${ }^{1} \&$ Syed Ahmed Salman ${ }^{1}$ \\ ${ }^{1}$ IIUM Institute of Islamic Banking and Finance, Kuala Lumpur, Malaysia \\ Correspondence: Syed Ahmed Salman, IIUM Institute of Islamic Banking and Finance, No.11, Jalan Bullion \\ Mewah 12, Taman Bullion Mewah, Batu Caves, Selangor 68100, Malaysia. E-mail: salmaniium@gmail.com
}

\author{
Received: August 4, 2013 Accepted: October 21, 2013 Online Published: December 31, 2013 \\ doi:10.5539/ass.v10n1p117 URL: http://dx.doi.org/10.5539/ass.v10n1p117
}

\begin{abstract}
Insurance has been widely used as a risk mitigation tool in our personal lives as well as in business world. It is not deniable that insurance has become part of parcel of our daily lives and it provides the benefits and protection to us when we are unfortunate. However, the concepts of riba (interest), gharar (uncertainty) and mysir (gambling) inherited in insurance principles and practices are prohibited from the Islamic perspective. The Muslim scholars introduced takful to replace the conventional insurance. Tremendously, takaful is at high growing rate and penetrating into both Muslim and Non-Muslim countries. However, to the extent of our knowledge, there are no takaful operators in India even though it has the second highest population and at the same time, third highest Muslim population in the world belongs to India. Thus, the aims of this study are to examine the acceptability and possibility of offering takaful in India and to propose the most suitable takaful model that should be engaged by the takaful operators and policy holders. The findings from 216 Muslim and 117 non-Muslim respondents show that acceptability of takaful by Indians regardless of Muslims or non-Muslims is very high and there is possibility that takaful products can be marketed in India. It seems regardless of the religion, takaful seems to be accepted by Indians. Moreover, 10 Shari'ah scholars 7 takaful operators and 5 consultants opine that hybrid model, i.e. the combined concept of wakalah and mudarabah, will be the most suitable model for India. Hence, future research should examine the perception of regulators to introduce takaful and economic viability of the proposed model.
\end{abstract}

Keywords: acceptability, possibility, Takaful, insurance and India

\section{Introduction}

Nowadays, the insurance becomes unavoidable instrument to be engaged by the human being regardless of the religion. It is mainly due to the complex nature of our life styles and business activities. In addition, the government regulation makes us engage with the insurance policy, for instance, buying car insurance to renew the road tax. The main purpose of insurance is to provide the coverage for the policy holders in the case of misfortune. This noble objective of insurance practices is acknowledged and appreciated since it helps the human beings for emergency. However, the inherited elements in the insurance practices such as interest, uncertainty and gambling make Muslim scholars think to come out with an alternative insurance which is not against with the teaching of Islam. In 1972, Malaysian National Fatwa Council and in 1985, Islamic Fiqh academy under the patronage of the Organization of Islamic conference (OIC) in it resolution no. $9(2 \backslash 9)$ declared that insurance is prohibited from the Islamic perspective.

Takaful is designed for everyone regardless of the religion. It could manage to penetrate the insurance markets in both Muslim and non-Muslim countries. Its growth rate is impressive and it has been evidenced by the World Takaful Report (2012) and Islamic Finance News (May, 2012). According to their records, Takaful industry has seen double digit growth since 2010 and Global Takaful contributions grew by $19 \%$ in 2010. India has a high potential for future takaful due to its third largest Muslim population (177 millions) in the world and its economic growth (per capita income $=\$ 3,194$ ). In addition, its insurance penetration rate is $5.1 \%$ and thus, it is the highest penetration rate among the potential takaful markets; namely, Turkey, CIS region, Russia, Bangladesh, Indonesia, Pakistan, Egypt, Nigeria, Algeria and Morocco. However, to our knowledge, there is no survey conducted to examine the Indians' acceptability of takaful products and possibility of introducing it. Therefore, the aim of this paper is to find out the acceptability and possibility of offering takaful in India.

The paper is organized in six parts. The second part explains the background of insurance in India. The third part 
elaborates on the concepts and principles of takaful. The fourth part explains the research methodology adopted in this study. The fifth the findings and finally, it concludes.

\section{Insurance in India}

According to the Insurance Regulatory and Development Authority (2013), the Oriental Life Insurance was established in 1818 and it was followed by the Bombay Assurance Company in 1823. Later on, in 1829, the Madras Equitable Life Insurance Society was established. The purpose of these insurance operators was to protect the lives of European people in India. British Insurance Act was introduced in 1870 and there were three Indian insurance companies were established in Bombay; namely, Bombay Mutual in 1871, Oriental in 1874 and Empire of India in 1879. However, during that time, insurance market was dominated by the foreign companies.

In 1912, Indian Life Insurance Companies Act was introduced and it is the first Act to mold the life insurance operators. Indian Insurance Companies Act (1928) was meant for all types of insurance operators. In 1950, the Insurance Amended Act was implemented after consolidating the previous Acts. Due to the increasing number of insurance operators and unethical insurance practices, the whole insurance industry was nationalized in 1956. In the same year, the government operated Life Insurance Corporation and the industry was monopolized until the late 1990s. In 2000, the Insurance Regulatory and Development Authority (IRDA) became the statutory body to monitor the insurance operators since the government again allowed private companies to run the insurance business. Starting from that, the insurance industry in India is tremendously growing.

The insurance penetration measured by the ratio of premium (in USD) to GDP (in USD) shows that for life insurance, the penetration rate increased from 2.15 in 2001 to 3.4 in 2011 and for non-life insurance, 0.56 in 2001 to 0.7 in 2011 . This shows that the penetration rate has been increased due to the privatization.

In 2010-2011, the life insurers underwrote premium of 126,381 crore $(1,263.81$ billion) as compared with 109,894 crore (1,098.94 billion) in 2009-10 archiving a lower progress of 15 per cent against 25.84 per cent of 2009-10. In terms of connected and non- connected organization during the year 2010-11, 37.38 per cent of the total premium was underwritten in the linked division. While 62.62 per cent of the organization was in non-connect division (43.52 and 56.48 per cent relevantly in 2009-10). The total premium underwritten by the life insurance sector in 2010-11 was 2, 91,605 crore (2916.05 billion) as against 2, 65,447 crore (2654.47 billion) in 2009-10 revealing a progress of 9.85 per cent (19.69 per cent in 2009-10) (IRDA, Annual Report, 2010-2011).

The non-life insurers underwrote premium of 42,576 crore (425.76 billion) in $2010-11$, in contrast 34,620 crore (346.20 billion) in 2009-10 archiving a growth of 22.98 percent against growth of 14.06 percent in the former year. In the non-life lines of business, the Health is division constantly rising in terms of its share to the total non-life premium. The share of health increased further to 23.35 per cent in 2010-11 (21.12 percent in 2009-10 and 20.06 per cent in 2008-09) (IRDA, Annual Report, 2010-2011).

The total number of insurance operators became 48 in 2011. It includes 24 non-life insurance companies, 23 life insurance companies and 1 reinsurance companies. Edelweiss to Edelweiss Tokio Life Insurance Company was bestowed registration in the year 2011-12, raising the total number of insurance companies to 49 as at end of September 2011 (IRDA, Annual report, 2010-11).

\section{Takaful as an Ethical Based Insurance}

According to Mahmoud (2008), Takaful means jointly guaranteeing among the participants. It is founded on the concepts of mutual cooperation and risk sharing (Usmani, 2007; Zuriah \& Redzuan, 2009). According to the definitions provided by Malaysian Takaful Act (1984), AAOIFI's Accounting, Auditing and Governance Standards for Islamic Financial Institutions (2004/2005) and Islamic Financial Services Board (IFSB) and International Association of Insurance Supervisors (IAIS), Takaful is a system in which the participants contribute with the intention of helping among the participants in the case of misfortune.

If the history of the insurance idea is examined, it has been started before the time of the Holy Prophet Mohammed (s.a.w.) (Klingmuller, 1969). During the ancient time, the concept of 'Aqilah' is used to pay the compensation to the heir of the murdered person by the close kin of the (Billah, 2003). There has been a steady expansion of unconventional insurance practice in the $20^{\text {th }}$ century in both Gulf and other non -Muslim states. Nowadays, there are more than 200 players compared to less than 10 players in early 80 s. Therefore, it can be summed that Islamic or unconventional insurance has been widely spread to unconventional environment because the ethical aspect has been incorporated in the Islamic insurance.

\section{Research Methodology}

Since this study focuses on the acceptability and possibility of takaful in India and this is an exploratory in nature, 
questionnaire survey has been conducted. Questionnaire is constructed by using likert scale ranging from 1 to 5 , where $1=$ strongly disagreed to $5=$ strongly agreed. The sampling method used in this study is quota sampling and this method is recommended for the exploratory nature of research (Sekaran \& Bougie, 2010). Questionnaires are distributed to Muslims and Non-Muslims in three states in India, namely Kerala, Bangalore and Hyderabad. In addition, the experts are interviewed to know which takaful model will the best suitable model during the initial stage of offering it. Sekaran and Bougie (2010) further state that qualitative data achieved by interviewing folks at the exploratory stage might help to get better understanding and it is crucial for descriptive studies. The interviewees are the Sharia's advisors, Takaful operators and consultants who have experienced in providing the advisory service to set the Takaful operators. Delphi technique is used for interview.

\section{Findings}

\subsection{Profile of the Respondents}

Table 1. Profile of the respondents

\begin{tabular}{|c|c|c|c|c|c|c|}
\hline \multirow[t]{2}{*}{ Questions } & \multicolumn{2}{|c|}{ Muslims } & \multicolumn{2}{|c|}{ Non-Muslims } & \multicolumn{2}{|c|}{ Overall } \\
\hline & Frequency & Percentage & Frequency & Percentage & Frequency & Percentage \\
\hline \multicolumn{7}{|l|}{ Gender of the respondent } \\
\hline Male & 135 & 62.5 & 66 & 56.4 & 201 & 60.4 \\
\hline Female & 81 & 37.5 & 51 & 43.6 & 132 & 39.6 \\
\hline \multicolumn{7}{|l|}{ Respondent's Age } \\
\hline 30 and below & 32 & 14.81 & & & 32 & 9.61 \\
\hline $31-50$ & 140 & 64.81 & 91 & 77.78 & 231 & 69.37 \\
\hline 51 and above & 44 & 20.38 & 26 & 22.22 & 70 & 21.02 \\
\hline \multicolumn{7}{|l|}{ Respondent's Education Background } \\
\hline Below degree (Diploma and Certificate) & 73 & 33.80 & 45 & 38.46 & 118 & 35.43 \\
\hline Degree & 62 & 28.70 & 18 & 15.38 & 80 & 24.03 \\
\hline Above degree (Masters and Ph.D.) & 81 & 37.50 & 54 & 46.16 & 135 & 40.54 \\
\hline \multicolumn{7}{|l|}{ What is your religion? } \\
\hline Muslim & & & & & 216 & 64.86 \\
\hline Non-Muslims & & & & & 117 & 35.14 \\
\hline \multicolumn{7}{|l|}{ Occupation } \\
\hline Employed & 199 & 92.13 & 106 & 90.60 & 305 & 91.59 \\
\hline Unemployed & 17 & 7.87 & 11 & 9.40 & 28 & 8.41 \\
\hline \multicolumn{7}{|l|}{ Personal Income } \\
\hline Rs 20,000 and below & 85 & 39.35 & 25 & 21.37 & 110 & 33.03 \\
\hline Rs $20,001-40,000$ & 107 & 49.54 & 77 & 65.81 & 184 & 55.26 \\
\hline More than Rs 40,000 & 24 & 11.11 & 15 & 12.82 & 39 & 11.71 \\
\hline
\end{tabular}

The profile of the respondents can be referred to Table 1. Total questionnaire of 500 are distributed. There are 216 Muslims respondents (out of 250 questionnaire distributed) and 117 non-Muslim respondents (out of 250 questionnaire distributed). The response rate of Muslims and non-Muslims are $86.4 \%$ and $46.8 \%$ respectively. Overall, response rate is $66.6 \%$. Most of the respondents are male. Most of the respondents' age range is 31-50. In the case of education, majority of the respondents are master and Ph.D. holders and followed by degree holders in both categories of respondents. Majority of the respondents are Muslims since the total number of Muslim respondents is 216 while that of non-Muslims is 117. Almost all of the respondents are employed since the percentage of Muslim respondents is $92.13 \%$ and that of non-Muslims is $90.60 \%$. Overall, $91.59 \%$ of the respondents are employed. Regarding personal income, the highest percentage of respondents are from the 
middle class with the income rage (Rs 20,001-40,000), followed by the income range (Rs 20,000 and below) and the income range (more than Rs 40,000) in both groups.

\subsection{Acceptability of Takaful in India}

Table 2. Acceptability of Takaful

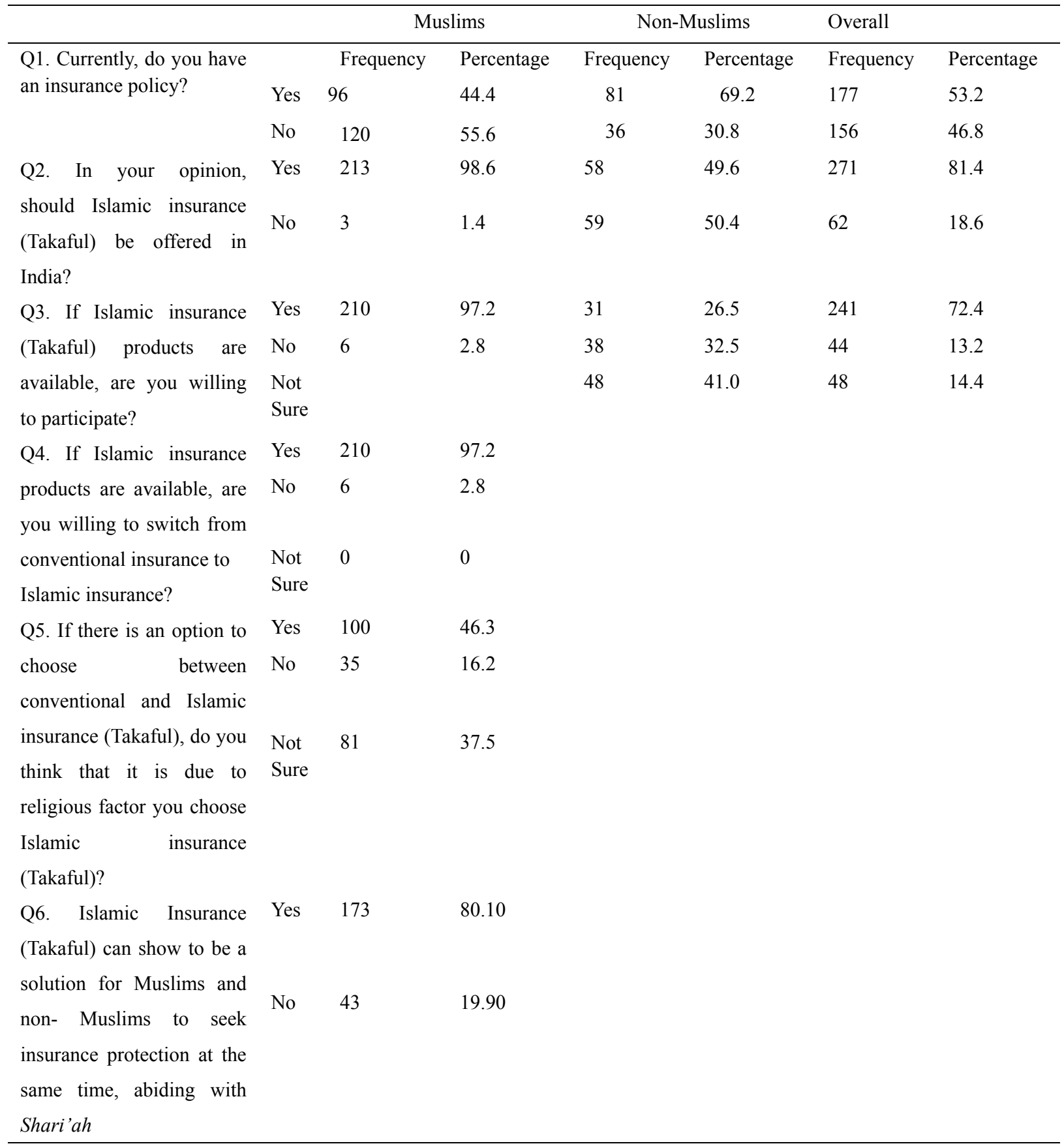

In order to examine the acceptability of takaful products, six questions are asked to the respondents and the findings are discussed in Table 2.

Among the respondents, majority of the respondents (53.2\%) have insurance policy. 81.4\% of the respondents believed that takaful products should be available in India, especially from the Muslim respondents since 98.6\% of them support the introducing of takaful. In the case of Non-Muslims, $49.6 \%$ of them think that takaful should be introduced while $50.4 \%$ do not. 
When the respondents are asked whether they want to participate if takaful products are introduced, $72.4 \%$ of overall respondents and $97.2 \%$ of Muslim respondents would like to participate. In the case of Non-Muslim respondents, $41 \%$ of them are undecided.

$97.2 \%$ of the Muslim respondents responded that if takaful products are available in Indian market, they prefer to choose takaful products and $46.3 \%$ of them believe that religious factor plays an important role in this decision. Moreover $80.1 \%$ of the Muslim respondents wish to have takaful products in India since it can provide protection to all the participants regardless of the religion.

Therefore, it can be summarized that the acceptability of takaful is very high in Indian market, especially from the Muslims.

\subsection{Possibility of Introducing Takaful in India}

Table 3. Possibility of introducing Takaful in India

\begin{tabular}{|c|c|c|c|}
\hline \multirow{2}{*}{ Questions } & \multicolumn{3}{|c|}{ Mean } \\
\hline & Muslims & Non-Muslims & Overall \\
\hline $\begin{array}{l}\text { Q1. Takaful provides a new business opportunity for the insurance } \\
\text { operators if they want to extend the product line. }\end{array}$ & 4.36 & 3.38 & 4.01 \\
\hline $\begin{array}{l}\text { Q2. Takaful has a good potential for fast development in the insurance } \\
\text { market. }\end{array}$ & 4.21 & 4.01 & 4.14 \\
\hline $\begin{array}{l}\text { Q3. Takaful provides wide range of opportunities for existing insurance } \\
\text { operators to attract the Muslim customers. }\end{array}$ & 4.40 & 3.98 & 4.25 \\
\hline $\begin{array}{l}\text { Q4. Takaful products should be available to meet the needs of all sectors } \\
\text { of economy both at corporate and individual level. }\end{array}$ & 4.26 & 4.22 & 4.25 \\
\hline $\begin{array}{l}\text { Q5. It is certain that Takaful will be beneficial for both Muslims and } \\
\text { non-Muslims. }\end{array}$ & 4.42 & 3.83 & 4.21 \\
\hline $\begin{array}{l}\text { Q6. It is believed that participation in takaful is more beneficial than } \\
\text { participation in traditional Conventional Insurance because surplus } \\
\text { (profit) will be distributed back to the participants. }\end{array}$ & 4.38 & 4.48 & 4.41 \\
\hline $\begin{array}{l}\text { Q7. Takaful may reduce unemployment and poverty among Muslims } \\
\text { since it is important to have Muslim employees, e.g. agents, to promote } \\
\text { the unconventional insurance products }\end{array}$ & 4.35 & 4.15 & 4.28 \\
\hline $\begin{array}{l}\text { Q8. It is said that takaful helps the weaker and unlucky people of the } \\
\text { society through various products. }\end{array}$ & 4.33 & 4.15 & 4.27 \\
\hline $\begin{array}{l}\text { Q9. There is no doubt that a huge potential for takaful in India exists, } \\
\text { but, it will need some strong supporting policy to make it a reality. }\end{array}$ & 4.35 & 4.04 & 4.24 \\
\hline $\begin{array}{l}\text { Q10. Muslim population in India stands at number third in world after } \\
\text { Indonesia and Pakistan that creates a gigantic potential for takaful and } \\
\text { hence, India should have takaful. }\end{array}$ & 4.56 & 4.41 & 4.51 \\
\hline
\end{tabular}

In order to examine the possibility of introducing takaful in India, ten questions are asked to the respondents. It has been found out that there is a strong support for introduction of takaful products in India. The findings are discussed in Table 3.

The respondents firmly believe (the overall mean value of 4.01) that it is a good opportunity for the existing insurance operators to extend the product line by introducing takaful products. The respondents are asked whether takaful has a good potential for fast development in the insurance market, the overall mean value of 4.14 evidences that takaful can penetrate the insurance market with rapid growth in gaining market share. Furthermore, the overall mean value of 4.25 indicates that the existing insurance operators will be able to attract the Muslim customers. Consequently, takaful can help the current insurance operators to get more takaful contribution or premium and directly it will results in higher profitability for the insurance operators.

When offering takaful products in the future, most of the respondents strongly believe (overall mean value $=4.25$ ) 
that Islamic Insurance products should be adequate to meet the needs of all sectors of economy both at corporate and individual level. Moreover, it is strongly recommended that takaful should fulfill the needs of everyone regardless of the religion (the overall mean value of 4.21). Respondents strongly (overall mean value of 4.41) expect that the participation in takaful is more beneficial than participation in traditional conventional insurance because the participants are entitled to receive the surplus or profit portion.

The respondents also strongly believe that introducing takaful will reduce unemployment and poverty among Muslims since it is important to have Muslim employees, e.g. agents, to promote the Islamic insurance products. It has been supported by the mean value of 4.28. In the case of discharging the corporate social responsibility of the insurance operators, the respondents strongly (the mean value of 4.27) expresses that insurance operators will be able to help the weaker and unlucky people of the society through various takaful products.

It is undeniable that a huge potential for takaful exists in India, but the overall mean value of 4.24 shows the respondents strongly believe that there is an urgent call for the strong supporting policy to introduce takaful successfully. Majority of the respondents strongly agree (the overall mean value of 4.51) that takaful should be offered since India is ranked as the third place in term of Muslim population all over the world.

\subsection{Findings from Interviews}

Since both Muslims and non-Muslims in India are willing to engage with Takaful products, experts were interviewed to explore which Takaful model will be the best suit model to offer. The interviewees are selected from Malaysia since it is one of the leading countries in Islamic finance. Delphi technique is used in conducting the interviews, after the third round of the interviews to 10 Shari'ah advisors, 7 Takaful operators and 5 consultants, it has been concluded that the following model, i.e. hybrid model based on the combined concept and Wakalah and Mudarabah, will be the most suitable model to be used in the Indian market. The proposed model can be referred to the following chart.

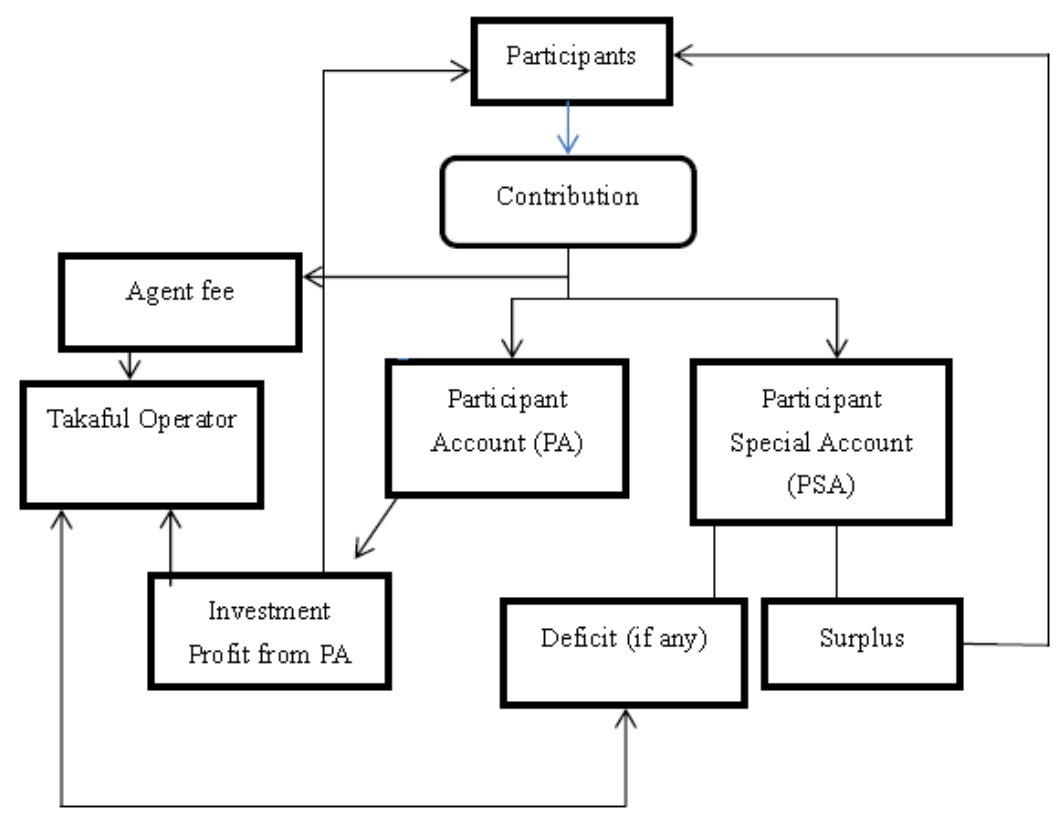

Figure 1.

When the participants make the contribution, the agent fee will be paid to the Takaful operator. The balance of the contribution amount will be allocated to the participant account (PA) and the participant special account (PSA). PA is the participant's personal account and it belongs to the respective participant only. Takaful operator will utilize the money from PA account for the investment and any proceed is distributed between the Takaful company the participant. PSA can be termed as Takaful risk fund which is pooled from all participants in order to help mutually among the participants in the case of misfortune. Similar the PA, Takaful operator will use the amount in PSA for the investment. In addition, this account will be used to pay the expenses related to retakaful and claims. If there is any surplus (the profit from the investment exceeds the expenses), will be channeled to the participant. However, in the case of deficit (the profit from the investment is less than the expenses incurred), 
interest free loan will be given by the shareholders to the PSA. In sum, Takaful operator will be getting wakalah fee and the profit share from PA while taking their responsibility of managing the Takaful risk fund and taking care the deficit. Participants will enjoy the claims, profit from PA and surplus from PSA.

\section{Conclusion}

When the historical development of insurance is examined, it is undeniable that insurance becomes part and parcel of our daily life. However, due to the involvement of prohibited and unethical elements such as interest, gambling and uncertainty in conventional insurance, it is necessary to move a step forward to find a way to overcome this problem. One way is to adopt takaful instead of conventional insurance. Therefore, this study examines the acceptability and possibility of introducing takaful in Indian market. The findings from the questionnaire show that takaful is accepted regardless of religion and there is high possibility to introduce it. In addition, the interview results from 10 Shari'ah advisors, 7 Takaful operators and 5 consultants propose the best suit takaful model in India. This study limitation is that the opinions of insurance operators and regulators from India have not been included and hence, this limitation should be further examined. In addition, only three states, namely, Kerala, Bangalore and Hyderabad cover in this study and not all the states in India are taken for survey questionnaire and thus, in future, the survey may cover all the states. However, it will not affect the generalization of the results since it is believed that this research finding will open up the eyes of the Indian government to offer takaful in India for the benefits of all involved parties. In addition, the results of this research give the hope for Indian Muslims to offer takaful products in future.

\section{References}

Billah, M. M. (2003). Islamic and Modern Insurance principles and practices. Malaysia:Ilmiah Publishers.

Billah, M. M. (2007). Applied Takaful and Modern insurance. Malayisa: sweet and Maxwell Asia.

Insurance Regulatory Development Authority. (2013). History of insurance in India. Retrieved from $\mathrm{http}: / /$ www.irda.gov.in/ADMINCMS/cms/NormalData_Layout.aspx?page=PageNo4\&mid=2

Kassar, K. (2008). What's Takaful A guide to Islamic Insurance. Lebanon: Bisc Group, Beruit.

Klingmuller, E. (1969, January). The concept and development of Insurance in Islamic Countries. Islamic culture, 3.

Mahmoud, H. (2008). Insurance: Takalful gaining ground the actuary.

Morgan, T. W. (1993). Porter's laws of insurance. Landon: n.p.

Rahman, Z. A., \& Redzuan, H. (2009). Takaful $21^{\text {st }}$ century Insurance Innovation. Malaysia: Mc Graw Hill.

Sekeran, U., \& Bougie, R. (2010). Research method for business: skin building Approach (5th ed.). UK: John wiley and son ltd.

Sharma, D. (2009). Banking and Insurance. India: Rajat publications New Delhi.

Siddiqui, N. M. (1984). Insurance in an Islamic Economy. UK: The Islamic foundation London.

Usmani, M. J. (2007). Takaful paper presented at securities and exchange commission of Pakistan. Takaful conference in Karachi.

Vaughan, J. E., \& Vaughan, T. (2001). Fundamentals of risk and insurance (9th ed.). John Wiley and sons.

World Takaful Report. (2012).

Yassin, N., \& Ramly, J. (2011). Takaful: A study Guide. Malaysia: IBFIM.

\section{Copyrights}

Copyright for this article is retained by the author(s), with first publication rights granted to the journal.

This is an open-access article distributed under the terms and conditions of the Creative Commons Attribution license (http://creativecommons.org/licenses/by/3.0/). 